Historic, Archive Document

Do not assume content reflects current scientific knowledge, policies, or practices. 



\title{
native Plants from "The Land of the Sky"
} $.1931=$

$$
\begin{aligned}
& \text { LI B R A F Y }
\end{aligned}
$$

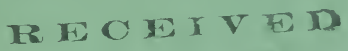

$$
\begin{aligned}
& \star \text { JUL } 191931 \text { x } \\
& \text { U. S. Department of Agrigulture. }
\end{aligned}
$$

nIK-nAR FARM

\author{
G. Latta Clement
}

Biltmore Station, Asheville, N. C. 


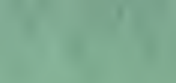

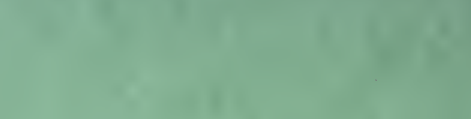

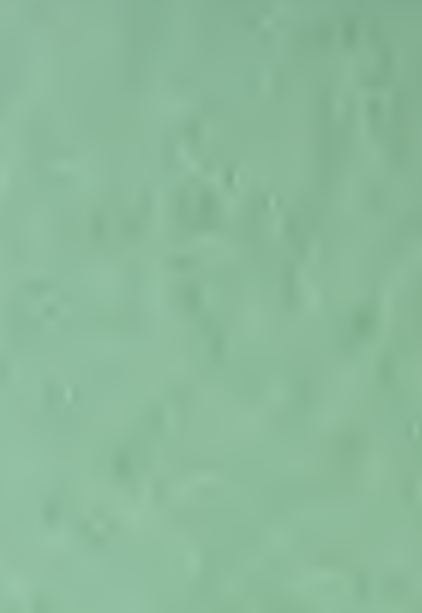

-

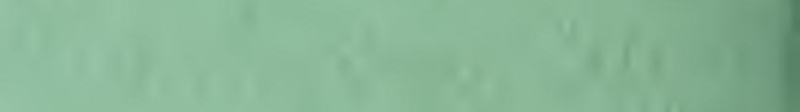

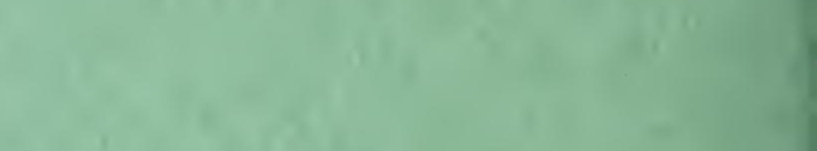

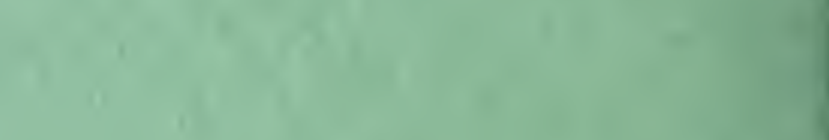

100 (2)

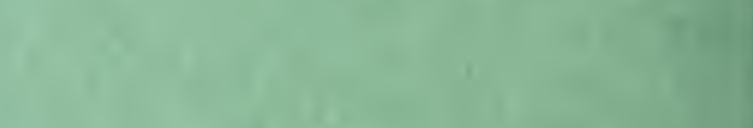

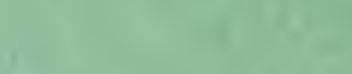

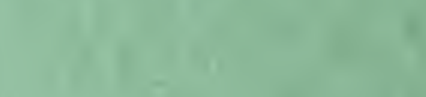

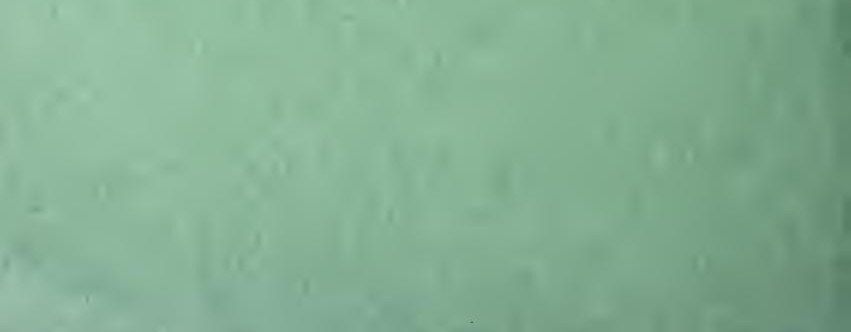




\section{native Plants from "The Land of the Sky"}

\section{nIK-nAR FARM}

G. Latta Clement

Biltmore Station, Asheville, N. C. 
Realizing that the public is fast waking up to the beauty of our native plants, and are adding them to their gardens, as well as building gardens to accommodate them, we have added the collecting of these plants to our nursery.

Knowing that we live in a section of the country adjacent to "The Great Smoky Mountains National Park" and "The Pisgah National Forest" in which the variety of flora cannot be equalled, we feel that this department will be appreciated by our customers.

Many of our most choice plants are fast becoming exterminated by vandals. We can save them from this fate by bringing them into cultivation, but we must plant them in conditions like they had in the wild. We have tried, in a small way, to give the kind of treatment they prefer. Further information along this line will be given our customers for the asking.

Orders for plants will be acknowledged as soon as received and shipped at the proper season, unless asked to be forwarded at purchaser's risk. Most plants should be transplanted after blooming and resting, however, many will move fully as well in bloom.

Our prices are $25 \mathrm{c}$ each, $\$ 2.00$ a dozen, $\$ 12.00$ a hundred, unless otherwise quoted. Cash must accompany all orders, unless satisfactory reference is given.

All plants are well packed and will carry to the most distant points. They are sent express collect, unless asked to be sent by parcel post and then postage is to be refunded by purchaser.

All claims must be sent in at once. We will make satisfactory adjustment, or refund the purchase price of plants. All customers must be satisfied.

We are co-operating with the State Chairman of the Conservatioon Department of the Garden Clubs of America. Conservation tags of approval will accompany orders when necessary.

If rare and unusual plants are wanted write us.

Quotations on carload lots of Rhododendrons, Kalmias, etc., on request. 


\section{A FEW OF OUR UNUSUAL PLANTS}

PACHYSTIMA CANBYI-An excellent evergreen ground cover of shrubby growth. Greenish-white flowers. Narrow oblong foliage.

HYMENOCALLIS OCCIDENTALIS (Spider Lily)-A hardy variety of this interesting amaryllis. White funnel shaped flowers in umbels on end of $2 \mathrm{ft}$. scapes. Perianth of six lobes extending beyond cuplike crown, stamens extending 2-3 in. above corolla, giving the effect of a large spider. Extremely fragrant but not offensive.

IRIS CRISTATA ALBA-An albino of the crested iris. Pure white flowers on 4 in. stems. Very dainty.

ATAMASOC LILY (Stagger Grass)-An amaryllis that grows in open meadows. Blossom 3 in. across on $1 \mathrm{ft}$. stems. White fading pink. Fragrant.

SHORTIA GALACIFOLIA (Oconee Bells)-Evergreen foliage turning bronze in fall. Beautiful white to pink flowers on 6 in. stems in March.

STEWARTT PENTAGYNA (Summer Dogwood)-A handsome shrub with cinnamon colored bark. Deep green foliage in summer. In July it bears numerous white flowers 2-4 in. in diameter. The blossoms have five cupped and serrated petals with a center of bright purple or yellow stamens. A most unusual and beautiful plant often growing $12 \mathrm{ft}$.

AESCULUS PAVIA (Dwarf or Red Buck-eye)-A shrub seldom growing more than $4 \mathrm{ft}$. tall. Has clusters of orange-red flowers in spring, followed by "Buck-eyes" in fall.

PHILADELPHUS LATIFOLIA-White flowers in loose clusters. Very fragrant. A shrub sometimes growing $15 \mathrm{ft}$. Very rare.

HYDRANGEA-DECUMBARIA BARBARA (Climbing Hydrangea)-A plant that climbs rockcliffs in damp places by aerial rootlets. Loose terminal corymbs of fragrant white flowers. Top-shaped capsules remain after seed fall away.

HUDSONIA MONTANA-Shrubby plant 6-8 in. tall, heather-like. Yellow flowers in summer. Entire plant changes to yellow in fall. $f$ ) 0 ह

COMPTONIA PEREGARINA (Sweet Fern)-Shrub $1-21 / 2 \mathrm{ft}$. Long leaves deeply pinnatified. Very fragrant when crushed. Dry hillsides.

KALMIA CUNITA-Seldom growing more than 18 in. Bright pink flowers. Prefers damp locations.

ROBINIA BOYNTONI (Pink Locust)-Long racemes of bright pink flowers. Practically thornless. $4 \mathrm{ft}$. 
ACONITUM UNCINATUM (Clambering Monkshood)Attractive blue flowers late in the summer. 4-8 $\mathrm{ft}$. $\$ 2.50$ doz.; $\$ 20.00100$.

ANEMONE QUINQUEFOLIA (Windflower)-Pure white blossoms in May. Quite pretty and easily grown. 4 in.

ANEMONE TRIFOLIA (Mountain Anemone)-Similar to windflower but leaves three divided. 6-8 in.

ANEMONE VIRGINIANA (Thimble Weed)-Flowers white to greenish. Stems hairy. $2-3 \mathrm{ft}$.

ANEMONELLA THALICTROIDES (Rue Anemone)Smaller blossoms than the windflowers but in clusters. One of the best. 6 in.

AQUILEGIA CANADENSIS (Columbine)-Very showy blossoms of red and yellow. Likes sun or shade. 1-2 ft.

ARISAEMA TRIPHYLLUM ( Jack-in-the-Pulpit)-Most interesting plants for deep shade. Easily grown. 1-2- ft.

ASARUM CANADENSE (Wild Ginger)-Leaves dark green, pubescent. Purplish-brown blossoms. Roots have strong flavor of ginger. Deep woods.

ASARUM VIRGINIANA (Heart Leaves)-Leaves glabrous, usually mottled. Urn-shaped purple blossoms. Rich woods.

ASCLEPIAS INCARNATA (Swamp Milkweed)-Likes damp places. Blooms of purplish red on $2 \mathrm{ft}$. stalks.

ASCLEPIAS TUBEROSA (Butterfly Weed)-One of our showiest flowers. Blossoms in June and July. Hot dry places. $2 \mathrm{ft}$.

ASTERS--In variety. Blues, lavenders and whites.

ASTILBE BITERNATA (False Goat's Beard)-Flowers yellowish white. A striking plant for damp shade. $4 \mathrm{ft}$.

BAPTISTIA TINCTORIA (Wild Indago)-Yellow peashaped flowers. Good foliage. Prefers open woods or full sun. $3 \mathrm{ft}$.

BAPTISTA AUSTRALIS (Indago)-Deep blue peashaped flowers. 3-4 $\mathrm{ft}$.

CALTHA PALUSTRIS (Marsh Marigold)-For wet places. Very bright yellow blossoms.

CAMPANULA CAROLINIA-A mist of small blue bells late in summer. $1 \mathrm{ft}$.

CHELONE GLABRA (T'urtlehead)-Blossoms similar to snapdragons, white. Likes moisture in either sun or shade. $2 \mathrm{ft}$.

CHELONE LYONI-Grows in either dry or damp soil. Large lavender-pink fiowers. 
CHIMAPHILA MACULATA (Spotted Wintergreen)Beautiful mottled leaves. Waxy white flowers. 4-6 in.

CIMICIFUGA AMERICANA (American Bugbane)Clusters of pretty white flowers. Open woods.

CIMICIFUGA RACEMOSA (Cohosh)-Spikes of white flowers in August. 4-6 ft.

CLAYTONIA VIRGINIA (Spring Beauty)-Dainty pink striped flowers. Early spring. Part shade. 4-6 in.

CLINTONIA BOREAIIS (Bluebeads)-Cream flowers similar to lilies. Spring. Bright blue berries in fall. 8 in.

CONVARLLARIA MAJALIS (Lily-of-the-Valley)-Deep woods. Spikes of white flowers in spring. 6-9 in.

DELPHINIUM TRICORN (Larkspur) - Deep blue flowers. $1 \mathrm{ft}$. Likes rocky slopes in sun.

DENTARIA DIPHYLLUM (Crinkleroot)-Clusters of - white flowers in early spring. $1 \mathrm{ft}$. Moist shade.

DICENTRA CANADENSES (Squirrel Corn)-Fernlike foliage. White heart-shaped flowers with pink edge.

DICENTRA CUCULLARIA (Dutchman's Breeches)Blossoms edged with yellow. Very dainty. Deep woods.

DICENTRA EXIMA (Plumy Bleeding Heart)-The best of the native bleeding hearts. Pink blooms all summer. Good foliage.

DODECATHON MEDIA (Shooting Star)-White flowers with brown eye. One of the very best. $2 \mathrm{ft}$. $\$ 2.50$ doz.; $\$ 20.00100$.

EPIGEA REPENS (Trailing Arbubtus) (Mayflower)Soft pink flowers in March. Very acid soil.

ERYTHONIUM AMERICANA (Trout Lily)-Spotted leaves and yellow lily-like blossoms.

EUPATORIUM AGEROIDES (White Snakeroot)-Heads of small white flowers in late summer.

ELPATORIUM PURPUREUM (Joe Pye Weed)-Purple heads of flowers in late summer. 6-8 ft. Damp places.

ERINGIUM YUCCAFOLIA (Sea Holly)-Very interesting plants with thistle like heads.

FERMS-Describbed by Britton and Brown.

ADIANTUM PEDATUM-Maidenhair.

ASPLENIUM FILIX-FOEMINA-Lady fern.

ASPIENIUM MONTANUM-Mountain spleenwort. 
ASPLENIUM PLATYNEURON-Ebony spleenwort.

ASPLENIUM 'TRICHOMANES-Maidenhair spleenwort.

BETRYCHIUM VIRGINIANUM-Virginia grape fern.

BETRYCHIUM TERNAT'UM-Ternate grape fern.

CHEILANTHES LANOSA-Hairy lip fern.

CHEILANTHES TOMENTOSA-Wooly lip fern.

COMPTOSORUS RHIZOPHYLLUS-Walking fern.

DICKSONIA PUNCTILOBULA-Hay scented fern.

DRYOPTERIS ACROTOCHOIDES-Christmas fern.

DRYOPTERIS MARGINALIS-Evergreen wood fern.

DRYOPTERIS NOVEBORACENSIS - New York fern.

DRYOPTERIS SPINULOSA-Spinulose shield fern.

DRYOPTERIS THELYPTERIS-Marsh shield fern.

LYGODIUM PALMATUM-Climbing fern. $\$ 2.50$ doz.; $\$ 20.00100$.

OSMUNDA CINNAMOMEA-Cinnamon fern.

OSMUNDA CLATONIANA-Clayton's fern.

OSMUNDA REGALIS-Royal fern.

PELLAEA ATROPUDPUREA-Purple stemmed cliffbrake. $\$ 2.50$ doz.; $\$ 20.00100$.

PHEGOPTERIS HEXAGOMOPTERA-Broad beech fern.

POLYPODIUM POLYPODIOIDES-Grey polypody.

POLYPODIUM VULGARE-Common polypody.

PTERIS AQUILNUM-Bracken.

WOODWARDIA AREOLATA-Net-veined chain fern.

FILIPENDULA RUBRA (Pink Spiraea)-Plumes of bright pink in July.

GALAX APHYLLA (Galax)-Spikes of white flowers in summer.

GAULTHERIA PROCUMBENS (Aromatic Wintergreen)-Creeping evergreen. Flowers white followed by red berries.

GENTIANA ANDREWSIA (Closed Gentian)-Intense blue flowers in September. 
GERANIUM MACULATUM (Wild Geranium) (Crane's Bill)-Many flowers of soft lavender, May until August.

GERANIUMI ROBERTIANUN (Herb Robert)-Red stems and smaller flowers than above. Likes stony places.

HELENILM AUTUMNALE (Sneeze Weed)-Bright yellow flowers. Fall. 3-4 ft.

HELIANTHUS (Wild Sunflower)-Blooms late in fall. Very showy.

HEUCHERA AMERICANA (Alum Root)-Beautiful marbled leaves. Feathery spikes of cream flowers in summer.

HEPATICA ACUTILOBA (Liverwort) - Early white starlike flowers from evergreen mottled foliage.

HEPATICA TRILOBA-Flowers usually blue-lavender. Round lobed leaves.

HOUSTONIA CAERULEA (Bluets) Biennials-Blue forget-me-not like flowers in May. 4 in.

HOLSTONIA REPTANS-Very dainty foliage creeping over stones. Prefers rich leaf mold. Flowers like above. Shade and moisture.

HOUSTONIA PURPUREA-A variety about 8 in. tall. Small blossoms and nearly purple.

HYPOXIS ERECTA (Yellow Star Grass)-Grasslike leaves. Yellow flowers on 6 in stems. Open woods.

IRIS CRISTATA (Crested Iris)-Flowers light blue, marked white. Excellent for rocky banks. 3-4 in.

IRIS CRISTATA ALBA-A pure white form of the above. Very rare. $\$ 2.00$ each.

IRIS PRISMATICA (Cubeseed Iris)-Grasslike foliage and narrow petaled flowers. Bogs and meadows.

IRIS PSEUDACORUS (Yellow Waterflag) - Bright yellow flowers in June. Grows anywhere. 3-4 ft.

IRIS VERNA (Vernal Iris)-Deep blue flowers with yellow centers. Open woods. 8 in.

IRIS VERSICOLOR (Blueflag)-Plant in masses in damp places. Very effective.

LEIOPHYLLUM PROSTRATA (Sand Myrtle)-Shrubby plant with evergreen foliage. Covered with pink blossoms in spring. $\$ 1.00$ each.

LIATRIS SPICATA (Gay Feather)-Tall spikes of rosy purple flowers in late summer.

LIATRIS SCARIOSA-Similar to above but larger blossoms.

(All lilies \$2.50 doz.; \$20.00 100.) 
LILIUM ATAMASCO (Zephyranthes Atamasco)-White fading pink. Fragrant. 10-12 in. tall. Open meadows.

LILIUM CANADENSE (Field Lily)-Yellow flowers on 3-4 ft. stalks. Damp woods or open meadows.

LILIUM CAROLINIANUM (Carolina Lily)-Open fields. Deep orange flowers. $2 \mathrm{ft}$.

LILIUM GREYI (Grey's Lily)-Small dark red lily. Likes very acid soil. Sun or shade.

LILIUM PHILADELPHICUN (Wood Lily)-Orange red. $2 \mathrm{ft}$.

LILIUM SUPERBUM (Turkscap Lily)-Very stately, often carrying thirty blooms at once. Orange colored. $5-8 \mathrm{ft}$.

LILIUM HYMENOCALLIS OCCIDENTALIS (Spider Lily) - Very rare. White fragrant flowers on $2 \mathrm{ft}$. stems. $\$ 2.00$ each.

LOBELIA CARDINALIS (Cardinal Flower)-A vivid red flower. Likes damp places. Grows 2-5 ft.

LOBELIA SPICATA-Small pale blue flowers. $2 \mathrm{ft}$.

LOBELIA SYPHILIT'TCA (Large Blue Lobelia)-Blossoms are a deep rich blue. Damp places.

LYCOPODIUM LUCIDULUM (Shining Club Moss)Likes deep woods soil and shade.

LYCOPODIUM OBSCURUM (Turkey Brush)-Bushy plants $6-8$ in. high.

LYCOPODIUM COMPLANATUM (Trailing Christmas Pine)-Long runners often $6 \mathrm{ft}$.

LYTHRUM ROSEUM SUPERBUM (Loosestrife)Rosy-purple flowers in late summer. A showy plant.

MÉNTHA SPICATA (Spearmint)-Attractive foliage plant. Useful for many purposes.

MIMILUM RINGERIS (Monkey Flower)-Grinning blue flowers on stems 2-3 ft. Like damp bogs or near streams.

MERTENSIA VIRGINICA (Virginia Bluebells)-One of the most beautiful wild plants. A blue and pink combination unsurpassed.

MITCHELLA REPENS (Turkey Berry)-An evergreen ground cover. White blossoms followed by berries in fall.

MITELLA DIPHYLLEA (Bishop's Cap) or (Mitrewort) -White flowers on stems $1 \mathrm{ft}$. in May. A good rock plant. 
MORNARDA DIDYMA (Wild Bergamont)-A brilliant scarlet in mid-summer. 3-4 ft. Likes moisture.

MYOSOTIS PALUSTRIS (Forget-Me-Not)-Excellent for brookside planting. Blooms all summer.

PACHISTIMA CANBYI-An evergreen ground cover, shrubby. Very rare. $\$ 1.00$ each.

PEDECULARI CANADENSE (Wood Betony)-Brown and yellow flowers on spikes 6-8 in. Ragged leaves. Open woods and hills.

PHLOX AMONEA (Hairy Phlox)-A bright pink color. Likes open woods or full sun. 6-8 in.

PHLOX CAROLINIA (Carolina Phlox)-Likes open woods. Stiff stems 1-2 ft. Pink blossoms.

PHLOX DECUSSATA (Tall Phlox)-From light pink to magenta. Open woods. $3-4 \mathrm{ft}$.

PHLOX OVATA (Mountain Phlox)-1-2 ft. Pink to red.

PHLOX DIVERICATA (Blue Phlox) -1 ft. Grows in part shade but likes full sun. Excellent.

PHLOX REPTANS (Creeping Phlox)-One of the best for a ground cover. Covered with lavender flowers in spring.

PHLOX SUBULATA (Moss Pink)-Does best in well drained sandy soil. Unsurpassed for rock work. 


\section{ORCHIDS}

CYPRIPEDIUM ACAULE (Moccasin Flower)-Pink. Acid soil. Part shade.

CYPRIPEDIUM PARVIFLORUM (Lady Slipper)Small yellow flowers. Fragrant. 1-2 ft. 50c each; $\$ 5.00 \mathrm{doz}$.

GOODYERA PUBESCENS (Rattlesnake Plantain)Beautiful white-veined leaves all year. Spikes of white flowers in summer.

HABENARIA CILIARIS (Yellow Fringed Orchid)Gorgeous orange-yellow flowers in August. 1-2 ft.

HABENARIA GRANDIFLORA (Large Purple Fringed Orchid)-Deep lavender flowers 2-5 ft. Open meadows.

HABENARIA PSYCODES (Smaller Purple Fringed Orchid)-Lilac flowers on spikes $1-3 \mathrm{ft}$. Very fragrant.

PAGONIA OPHIOGLOSSOIDES (Snake-mouth)-Solitary flowers of rose color. Fragrant. $1 \mathrm{ft}$.

LIMODORUM TUBEROSUM (Bearded Orchid)-Spikes of lavender flowers in summer. One of the prettiest.

ORCHIS SPECTABAILS (Showy Orchid)-Six inch spikes of lavender and white flowers. Deep leaf mold. Summer.

SPIRANTHES CERNUA (Ladies'. Tresses)-White fragrant flowers in fall. 8 in.

APLECTRUM SPICATUM (Adam and Eve) (Putty Root)-A most interesting plant. One leaf from corm forms in the fall. A spike of brownish-purple blossoms in spring. $2 \mathrm{ft}$.

OXALIS VIOLOCES (Woodsorrel)-Lavender flowers on 4 in. stems. Moist woods in summer.

POLYGONATUM BIFLORUM (Solomon Seal)-Cream colored bells on underside of stalk $1 \mathrm{ft}$. long. Blue berries in fall.

POLYGONATUM COMMUTATUM (Great Solomon Seal)-Like above but 3-4 ft.

RUDBECKIA HIRTA (Brown-eyed Susan)-Biennial. Brilliant orange flowers with large brown cone.

SAGGITARI LATIFOLIA-White flowers on $2 \mathrm{ft}$. stems. Bogs.

SANGUANARIA CANADENSIS (Blood-root)-Large waxy white flowers in early spring before leaves mature. One of the best. 6-8 in. Rich woods.

SARRACENIA RUBRA (Pitcher Plant)-A rare plant with long narrow pitchers. Red flowers. $1 \mathrm{ft}$. 50c each. 
SARRACENIA PURPUREA-Large open pitchers. Purplish-red flowers. $10-12$ in. $\$ 2.50$ doz.; $\$ 20.00100$.

SEDUM TERNATUM (Stonecrop)-An excellent ground cover for shady places. White blossoms in summer. Bunches in sun.

SEDUM TELPHOIDES-Similar to the cultivated Spectabilis, but has white blossoms. Stony places in sun.

SEDUM PULCHELLUM (Pink Stonecrop)-A creeping plant liking either sun or shade. Bright pink flowers.

SEDUM NEVII-Densely tufted. Flower branches 3-5 in. long. White. Prefers stone crevices. Very rare. 50c each.

SAXIFRAGE VIRGINICA (Mountain Saxifrage)Rosetts of bronzy leaves clinging to rock ledges. Spikes of white flowers in spring.

SENECIO AURENS (Ragwort)-Bright yellow clusters of flowers. Very showy. Grows anywhere.

SHORTIA GALACIFOLIA (Oconee Bells)-One of the rarest and most beautiful of plants. Evergreen leaves. Bell shaped white flowers in March. $\$ 2.50$ doz.; $\$ 20.00$ 100.

SILENE CAROLINIA-Beautiful pink flowers. Likes open sun and rock ledges.

SILENE STELLARI-White fringed flowers $2 \mathrm{ft}$.

SILENE VIRGINICA (Firepink)-Brilliant scarlet. $1 \mathrm{ft}$. June. Rock cliffs in sun or open woods.

SISYICHIUM AUGUSTIFOLIUM (Blue-eyed Grass)A cousin of the iris. Very dainty and pretty. Best in sun.

SMILANCINA RACEMOSA (False Solomon Seal)White plume of flowers at end of stalk. Red berries in fall.

THALICTRUM DIOICUM (Early Meadowrue)-Purplish flowers in May. $2 \mathrm{ft}$.

THALICTRUM POLYGANUM (Tall Meadowrue)White flowers. Summer, $4 \mathrm{ft}$.

TIARELLA CORDIFOLIA (Foam Flower) (False Miterwort)-Feathery heads of white flowers in May. 6-8 in. Good rock plant.

TRADESCANTHA VIRGINIANA (Spiderwort)-Grass like leaves. Violet flowers all summer. 2-3 ft.

TRADESCANTHA COMMELINA VIRGINICA (Virginia Day Flower)-Deep blue flowers, deep yellow stamens. Moist soil sun. 
TRILLIUM CERNUM (Nodding Trillum,-Pure white blossoms.

TRILLIUM ERECTUM (Wakerobin)-Deep dark red.

TRILLIUM GRANDIFLORUM (Snow Trillium)-White flowers fading pink.

TRILLIUM LUTEA (Golden Trillium)-Very rare. Blooms are a rich golden color. \$2.50 doz.; \$20.00 100 .

TRILLIUM STYLOSUM-Pink flowers. Very good.

TRILLIUM SESSILE (Sitting Trillium)-Deep red flowers. Handsome mottled foliage.

TRILLIUM UNDULATUM-White with rose veins. A beauty.

TYPHA LATIFOLIA (Cattail)-Very effective in bog planting.

UVALARIA PERFOLOATA (Merry Bells)-Cream nodding bell shaped flowers. $1 \mathrm{ft}$.

VIOLA BLANDA (Sweet White Violet)-Flowers white and slightly fragrant.

VIOLA CANADENSES (Canada Violet)-White veined purple.

VIOLA HASTATA (Halbard-leaved Violet)-Very bright yellow.

VIOLA LANCEOLATA (Lance-leaved Viola)-White with purple veins.

VIOLA PEDATA (Bird-foot Viola)-Deep blue color with divided leaves.

VIOLA PRIMULAEFOLIA (Primula-leaved Viola)White with purple veins.

VIOLA ROSTRATA (Long-spurred Viola)-Pale blue with very long spurs. A heavy bloomer. $\$ 2.50$ doz.; $\$ 20.00100$.

VIOLA ROTUNDIFOLIA (Round-leaved Viola)-Large round leaves. Yellow blossoms.

VIOLA SAGITTATA (Arrow-leaved Viola)-Deep blue flowers.

VIOLA TENELLA (Field Pansy) -A dainty very small viola. Blossoms of yellow, blue and purple.

VIOLA VILLOSA (Southern Wood Viola) - Very compact and free blooming. Blue.

ZYGADENUS MUSCAETOXICUS (Crow-poison) Spikes of white flowers on long stems. Grasslike leaves. $2 \mathrm{ft}$. 


\section{SHRUBS AND TREES}

All Shrubs B. \& B.

\section{Deciduous Shrubs}

AESCULUS PAVIA (Dwarf or Red Buckeye)-Interesting shrubs, seldom growing over $4 \mathrm{ft}$. Clusters of orangered flowers followed by "Buckeyes." 2-3 ft. \$1.00 each.

AMELANCHIER LAEVIS (Allegheny Service Berry)Covered in snowy-white flowers in spring. Followed by red berries. 2-3 ft. $75 \mathrm{c}$ each.

AZALEA ABORESCENS (Sweet Azalea)-Flowers white tinged pink. Fragrant. July and August. $1 \frac{1}{2}-2 \mathrm{ft}$. $75 \mathrm{c}$ each.

AZALEA CANDULACEA (Flame Azalea)-From deep cream to orange-red. The showiest of all native azaleas. 2-3 ft. \$1.00 each.

AZALEA CANESCENS (Mountain Azalea)-4-15 ft. Flowers rose to white appearing before the foliage. Very fragrant. Open woods. $\$ 1.00$ each.

AZALEA NUDIFLORA (Pinxter Flower)-Deep pink in early spring. Moist places best. 2-3 ft. $\$ 1.00$ each.

AZALEA VASEYI (Shellpink Azalea)-The most beautiful of all azaleas. $1-1 \mathrm{I} / 2 \mathrm{ft}$. $\$ 2.00$ each.

AZALEA VISCOSA (Swamp Azalea)-Very fragrant white flowers. Moist positions. 2-3 ft. $\$ 1.50$ each.

CALACANTHUS CAROLINIA (Sweet Shrub or Carolina Allspice) - A rare fragrance. Chocolate flowers in summer. $2-3 \mathrm{ft}$. $75 \mathrm{c}$ each.

CIRCUS CANADENSES (Judas Tree or Red Bud)Covered in pink pea-shaped flowers before the leaves appear. 2-3 ft. $75 \mathrm{c}$ each.

CORNUS FLORIDA (Flowing Dogwood)-Large white flowers in early spring. $2-3 \mathrm{ft}$. $75 \mathrm{c}$ each.

COMPTONIA PEREGRINA (Sweet Fern)-Shrub 1-2I/2 $\mathrm{ft}$. Long leaves deeply pinnatified. Very fragrant when bruised. Dry hills. $\$ 2.00$ each.

EUONYMUS AMERICANA (Strawberry Bush)-Reddish green foliage. Rough crimson berries in fall. 2-3 ft. $75 \mathrm{c}$ each.

HALESIA TETRAPTERA (Silver Bells)-Producing quantities of white bells in early spring. 2-3 ft. $75 \mathrm{c}$ each.

HAMAMELIS VIRGINIANA (Witch-hazel)-Good foliage. Large yellow fiowers just before the leaves fall in the autumn. $2-3 \mathrm{ft}$. $75 \mathrm{c}$ each. 
HYDR.ANGEA RADIATA (Wild Hydrangea)-Beautiful silvery foliage. White blossoms in July and August. $2-3 \mathrm{ft}$. $75 \mathrm{c}$ each.

HYDRANGEA DECUMARIA BARBARA (Climbing Hydrangea)-Grows fifteen feet, clinging to rocks by aerial rootlets. White blossoms. Very rare. $\$ 2.00$ each.

HYDRANGEA ARBORESCENS-Deep green foliage. $75 \mathrm{c}$ each.

HYDRANGEA QUERCIFOLIA (Oak-leaved Hydrangea)-Large oak-like leaves. Long panicles of white flowers. Excellent in cultivation. $\$ 1.00$ each.

ILEX MON'TICALA (Mountain Berry or Deciduous Holly)-Deep green foliage in summer. Loaded with bright berries in fall and winter. Damp places. 2-3 ft.

- 75 each.

ILEX VERTICILLATA (Virginia Winterberry)-Deep green leaves. Glabrous, bright red berries remaining late in winter. $75 \mathrm{c}$ each.

MAGNOLIA ACUMINATA (Cucumber Tree)-Conspicuous yellow-green flowers in May. Rose colored fruits in autumn. 2-3 ft. $75 \mathrm{c}$ each.

MAGNOLIA FRASERI (Ear-leaved Umbrella Tree)Large cream colored flowers. Rose colored fruits. $\$ 1.00$ each.

MAGNOLIA MACROPHYLLA (Large-leaved Cucumber Tree)-Large flowers with big purple centers. Bright rose fruits. $\$ 1.00$ each.

PHILADELPHUS GRANDIFLORA-Flowers $1 \frac{1}{2}-2$ in. at end of branches and sometimes axillary. White. Very showy. $\$ 1.00$ each.

PHILADELPHUS LATIFOLIA - White flowers in clusters in spring. Very fragrant. Sometimes growing $15 \mathrm{ft}$. Extremely rare. 2-3 ft. \$2.00 each.

ROBINIA BOYNTON (Pink Locust)-Shrub about $4 \mathrm{ft}$. high. Long racemes of clear pink flowers. Almost thornless. $\$ 1.00$ each.

ROBINIA HISPIDA (Pink Locust)-Interesting shrubs with panicles of bright pink flowers in spring. $75 \mathrm{c}$ each.

ROBINIA PSEUDACACIA (Yellow Locust) - Large panicles of white flowers. Very fragrant. Extensively cultivated. $75 \mathrm{c}$ each.

SAMBUCUS CANADENSES (American Elder)-Grows 4-10 ft. Flowers white. Deep purple fruits in autumn. $\$ 1.00$ each.

SAMBUCUS PUBENS (Red-berried Elder)-Panicles of white flowers followed by scarlet fruit. $\$ 1.00$ each. 
SPIREA TOMENTOSA (Steeple-bush)-Erect, shrubby, usually simple stems. Flowers in terminal panicles. Pink. $75 \mathrm{c}$ each.

SPIREA LATIFOLIA-Shrub 2-4 ft. Panicles of white flowers.

STEWARTIA PENTAGYNA (Summer Dogwood)Large white flowers in July. Very showy and beautiful. $2-3 \mathrm{ft} . \$ 2.00$ each.

VIBERNUM ACERFOLIA (Mapleleaf Virburnum)-Flat white flowers followed by black berries. 2-3 ft. 75c each.

\section{EVERGREEN SHRUBS AND TREES}

ILEX GLABRA (Inkberry)-Bushy shrub. Dark green shiny foliage. Abundance of black berries in fall. 1-1 $1 / 2$ ft. $\$ 1.50$ each.

ILEX OPACA (American Holly) - Small tree. Dark green thorny leaves. Bright red berries all winter. $1-1 \frac{1}{2} \mathrm{ft}$. $\$ 1.50$ each.

KALMIA AUGUSTIFOLIA (Sheep Laurel)-Low shrub. Crimson flowers in compound umbels. 6 in. to $1 \mathrm{ft}$. $\$ 1.00$ each.

KALMIA CUNITA-Seldom growing more than 18 in. Deep pink blossoms. Prefers damp situations. $\$ 2.00$ each.

KALMIA LATIFOLIA (Mountain Laurel)-Dark green shiny foliage. Rose colored flowers in abundance. 2-3 ft. $\$ 1.00$ each.

LEUCOTHEA CATAWBAEI-Shiny dark green foliage turning bronzy-red in fall. Fragrant white flowers in pendulant racemes. $1-1 \frac{1}{2} \mathrm{ft}$. $\$ 1.00 \mathrm{each}$.

PIERUS FLORIBUNDA (Andromeda)-Compact shrub. Small dark green leaves. White flowered panicles at end of branches. $1-1 \frac{1}{2} \mathrm{ft}$. $\$ 2.00$ each.

RHODODENDRON CAROLINIANA-Very early to flower. Beautiful white to pink blossoms in profusion. $2-3 \mathrm{ft}$. $\$ 2.00$ each.

RHODODENDRON CATAWBIENSE-Very hardy and free flowering. Deep lavender-pink flowers in June. $2-3 \mathrm{ft}$. $\$ 2.00$ each.

RHODODENDRON MAXIMUM-Large foliage. Pink to white flowers. Unexcelled for woodland planting. $2-3 \mathrm{ft} . \$ 2.00$ each.

RHODODENDRON PUNCTATUM-Very similar to Caroliniana but has bright pink flowers. Foliage turns bronzy-red in winter. 1-2 ft. $\$ 2.00$ each. 
PACHYSTIMA CANBYI-Excellent ground cover. Narrow oblong foliage. Very rare. 8 in. to $1 \mathrm{ft}$. $\$ 1.00$ each.

TSUGA CANADENSES (Canada Hemlock)-One of our best evergreens. Good for hedges if kept clipped. 2-3 ft. $\$ 1.50$ each.

TSUGA CAROLINIANA (Carolina Hemlock)-The most graceful and beautiful tree we have. $1-2 \mathrm{ft}$. $\$ 1.50$ each. 
